\title{
Mevsimsel Yağışların Jeoistatistiksel Yöntemle Modellenmesi ve Gözlemi Olmayan Noktalarda Tahmin Edilmesi
}

\author{
Hatice ÇITAKOĞLU ${ }^{1}$ \\ Mahmut ÇETIN ${ }^{2}$ \\ Murat ÇOBANER ${ }^{3}$ \\ Tefaruk HAKTANIR ${ }^{4}$
}

$\ddot{O Z Z}$

Yağış zamansal ve mekansal olarak fazla değişkenlik gösteren bir meteorolojik veridir. Literatürde yağışların zamansal değişimi ile ilgili pekçok araştırma yayını mevcuttur. Bu çalışmada, Türkiye genelinde gözlenmiş aylık yağış verileri kullanılarak, jeoistatistiksel yöntemle mevsimsel yağışların mekansal değişimleri incelenmiştir. Bunun için, Türkiye sınırları içerisinde yer alan 20 yıl ve daha fazla kayıt uzunluğuna sahip 200 adet yağış gözlem istasyonunun Ocak-Aralık dönemine ait aylık ortalama yağış değerleri kullanılmıştır. Dört mevsim yağış haritalarının Gaussian tip yarıvariogram ile temsil edilebileceği ve mevsimsel yağgş̧ların mekânsal değişiminin jeoistatistik yöntem ile yeterli doğrulukta tahmin edilebileceği gösterilmiştir. Çalışmanın sonucunda, yağış ölçümü olmayan coğrafik konumlarda mevsimsel yağış miktarlarının kolaylıkla ve doğru olarak tahmin edilebilmesi sağlanmıştır.

Anahtar Kelimeler: Mevsimsel yağışlar, jeoistatistik, kriging, yarıvariogram.

\begin{abstract}
Modeling of Seasonal Precipitation with Geostatistical Techniques and Its Estimation at Un-gauged Locations

Precipitation is a meteorological data exhibiting large variations both temporally and spatially. There are quite a few research publications in literature related to temporal variation of precipitation. In this study, the spatial variation of seasonal precipitation is investigated using the monthly precipitation data measured all over Turkey. For this purpose, the monthly average values pertaining to the January-December period based on recorded data of at least 20-year length observed at 200 rain-gauging stations existing within the boundaries of Turkey are used. It is determined that the precipitation maps of
\end{abstract}

Not: Bu yazı

- Yayın Kurulu'na 05.06.2015 günü ulaşmıştır.

- 31 Mart 2017 gününe kadar tartışmaya açıktır.

1 Erciyes Üniversitesi, İnşaat Mühendisliği Bölümü, Kayseri - hcitakoglu@erciyes.edu.tr 2 Çukurova Üniversitesi, Tarımsal Yapılar ve Sulama Bölümü, Adana - mcet64@cu.edu.tr 3 Erciyes Üniversitesi, İnşaat Mühendisliği Bölümü, Kayseri - mcobaner@gmail.com

4 Erciyes Üniversitesi, İnşaat Mühendisliği Bölümü, Kayseri - thaktan@erciyes.edu.tr 
Mevsimsel Yağışların Jeoistatistiksel Yöntemle Modellenmesi ve ...

four seasons can be depicted by a Gaussian type semivariogram and the spatial variation of seasonal precipitation can be estimated by this geostatistical method at sufficient accuracy. The outcome of the study enables the magnitude of seasonal precipitation at ungauged geographical locations to be estimated easily with sufficient accuracy.

Keywords: Seasonal precipitation, geostatistics, kriging, semivariogram.

\section{GİRIŞ}

Hidroloji ve su kalitesi dâhil olmak üzere havza yöntemi uygulamalarında yağış yüksekliği önemli bir parametredir. Yağış yükseklikleri, yağış gözlem istasyonlarındaki standart yağış ölçeklerinde noktasal olarak mm birimiyle ölçülür. Yeryüzündeki her noktaya bir gözlem istasyonu kurma olanağı bulunmadığı için her noktada gözlem yapmakta mümkün değildir. Ayrıca, tek bir ölçer kullanılarak belirlenen yağı̧s yüksekliği, yüzey akışında belirsizliklere neden olmaktadır [1,2]. Özellikle, çalışma alanına uzak yağış ölçerin kullanılması akış, yer altı su seviyesi ve toprak neminin tahmininde zorluklara neden olmaktadır [3]. Havza bazında yapılan büyük ölçekli su kaynaklarının sürdürülebilir yönetim çalışmalarında yağış verilerinin zamansal ve özellikle mekânsal değişimi önemli bir parametredir. $\mathrm{Bu}$ nedenle, mühendislik çalışmalarında sıkça ihtiyaç duyulan ve belirlenmiş bir alan üzerindeki ortalama yağış derinliğini ifade eden alansal yağışın ölçülmesi de olası değildir [4]. Dolayısıyla, alansal yağış, bir takım yöntemler kullanılarak hesaplanmaktadır.

Gözlem yapılamayan noktalardaki gerek alansal gerekse noktasal yağış tahminleri, aritmetik ortalama, Thiessen poligonları, optimum enterpolasyon, izohiyet eğrileri vb yöntemlerden biri kullanılarak hesaplanabilmektedir. Ancak, bu yöntemlerle yapilan tahminler genelde objektif olmayıp; yetersiz ve yanlıdır. Ayrıca bu yöntemler, yapılan tahmine ilişkin varyans hakkında bilgi de verememektedir [4]. Ülkemizde noktasal ve alansal yağış tahminlerinde en sık kullanılan yöntem Thiessen poligonları yöntemidir. $\mathrm{Bu}$ yöntemde yağışın karakteristik özellikleri ve üzerinde çalışılan havzanın fizyografyası göz önüne alınmamakta, izohiyet eğrileri yönteminde ise, izohiyetler çizilmeden önce bölgedeki gözlem istasyonları verileri arasındaki bağımlılık derecesi ve bağımlılık yapısı hakkında bir ön çalışma yapılmamaktadır $[4,5]$.

Hidrometeorolojik veriler olasıllğa bağlı değişkenler olup alansal tahminlerde bu tür verilerin kullanılabilmesi amacıyla esas bileşenler analizi kullanılmaktadır. Esas bileşenler analizi bir alandaki gözlem istasyonları arasındaki kolerasyon fonksiyonuna bağlıdır. $\mathrm{Bu}$ yöntemle kısa periyotlu istasyonlardaki kaydedilmemiş verileri ve hiç gözlem yapılmamış noktalardaki değerler tahmin edilebilmektedir [6]. Önsoy ve ark. [7] 1929-1972 y1lları arasında gözlemlenen Türkiye'deki 40 istasyona ait yağış̧ verilerine esas bileşenler analizini uygulamıştır. Çalışmanın sonucunda ise bu yöntemin büyük bölgelerde hataların olabileceğini ve küçük havzalarda uygulaması, gerçeğe daha yakın sonuçlar vereceğini belirtmişlerdir. Hidrolojik değişkenlerin haritalamasında kullanılan bir diğer yöntem ise Üçgensel Hidrolojik Enterpolasyon (MTH) yöntemidir. Üçgensel hidrolojik enterpolasyon (MTH) yöntemi stasyoner bölgesel değişkenler üzerinde uygulanmakta olup her bir üçgenin düğüm noktaları arasında basit kübik enterpolasyon yapılmaktadır[8]. Önsoy ve Bayram [8], Türkiye'yi, üçgenler ağı oluşturarak, yağış değerlerinden oluşturulan korelasyon matrisi öz vektör değerlerinde uygulamasını yapmışlardır. Çalışmanın sonucunda diğer yöntemlerle pratik olarak aynı sonuçları verdiğini tespit edilmişlerdir. Önsoy ve Bayram [9], çalışmalarında Türkiye'nin tamamına MTH, Thiesen ve enterpolasyonlu elle çizim 
yöntemlerini uygulamışlardır. Çalışmalarının sonucunda, bu üç yöntem ile tahmin edilen yağı̧s değerlerinin, hemen hemen aynı olduğunu belirtmişlerdir. Ayrıca çalışmalarında kullandıkları MTH yönteminde, her bir üçgen ünite içerisinde varyansın sabit olması kabulü, üçgen üniteler büyüdükçe, zayıflayacağını belirtmektedirler. Karahan ve ark. [10] GAP bölgesinde yer alan meteoroloji istasyonlarına ait yağış Şiddet-Süre-Frekans ilişkisinin belirlenmesinde enlem, boylam ve yükselti verilerini kullanarak bağıntı geliştirmiş ve yağış ölçümü bulunmayan veya ölçüm süresi kısıtlı yerleşim yerlerinin yağış şiddet-süre-frekans ilişkisinin belirlenebileceğini ifade etmişlerdir.

Tarım alanlarında değişik amaçlara yönelik olarak yapılmış çalışmalarda, örnekleme yerlerinden alınan verilerin göstereceği değişkenliğin incelenmesinde, klasik istatistiksel yöntemler yeterli olmamaktadır. Çünkü klasik istatistikte herhangi bir değişkene ilişkin varyans ve standart sapmanın hesaplanmasında gözlemlerin yapıldığı yerin coğrafi konumu, gözlem noktalarının birbirlerine göre konumları ve gözlemler arasındaki korelasyon dikkate alınmamaktadır. Söz konusu soruna çözüm getirmek amacıyla Matheron, 1960'lı yıllarda "yöresel değişkenlik" kuramını ortaya atmıştır. Söz konusu teknik, ilk olarak maden mühendisliğinde maden rezervlerinin belirlenmesinde kullanıldığı için "Jeoistatistik" olarak tanımlanmıştır. Jeoloji biliminde kullanımı yaygınlaşan jeoistatistiksel yöntemler, zamanla diğer bilim alanlarında da kullanılmaya başlanmıştır. Örneğin; Çetin ve ark. [11] tarafindan yapılan bir çalışmada, toprak ve taban suyuna ilişkin bazı fiziksel ve kimyasal özellikler jeoistatistik ve probabilistik yöntemler kullanılarak incelenmiştir. Bu amaçla, incelenen değişkenlerin uzaysal bağımlılık yapıları modellenmiş ve haritalanarak alansal dağılımları saptanmıştır. Buytaert ve ark. [12] Thiessen poligonu ve kriging yöntemlerini kullanarak Güney Ekvador Andes' daki yağış verilerinin mekânsal ve zamansal değişkenliğini çalışmışlardır. Çalışmalarında, kriging yöntemiyle yapılan mekânsal enterpolasyonun, Thiessen poligonu ile yapılan mekânsal enterpolasyondan daha iyi olduğunu ve her iki yöntemin doğruluğu, dış eğilimler dâhil edildiğinde artabileceğini belirtmişlerdir. Basistha ve ark. [13] deterministik ve jeoistatistiksel yöntemleri kullanarak Hint Himalayalar'ındaki yağış verilerinin mekânsal dağılımını incelemişlerdir. Universal Krigingin en uygun yöntem olduğunu ve bu yöntemi sıradan kriging (ordinary kriging) ve Ters Mesafe Ağırlandırma (Inverse Distance Weighting, IDW) yöntemlerinin takip ettiğini belirtmişlerdir. Son yıllarda bazı araştırmacılar ise istatistiksel yöntemlerle elde ettikleri değerleri haritalama tekniklerini kullanarak çeşitli tekerrür periyotları için haritalar elde etmişlerdir. Karahan [14] (2011)'de ise Ege bölgesi meteoroloji istasyonlarının verilerini kullanılarak kümeleme analizi, L-Momentler ve optimizasyon algoritmaları (diferansiyel gelişim) ile eksik yağış şiddetleri tahmin edilmiş ve haritalandırmıştır. Çıtakoğlu [15], İç Anadolu Bölgesinin 31 adet meteoroloji istasyonuna ait 14 adet yağış serisi verilerine L-Momentler yöntemini uygulamış olup çeşitli tekerrür periyotları için jeoistatistik yöntemle haritalar elde etmiştir. Çalışmanın sonucunda ise ölçümü olmayan veya ölçüm süresi az olan yerlerdeki kısa periyotlu yağı̧ tahminlerinin bu haritalar yardımıyla elde edilebileceğini belirtmişlerdir.

Literatürde yapılan pek çok çalışmada yağışların yıllık bazda tahminleri yapılmaktadır. Dünya üzerindeki yağışların sadece yıllık bazda tahminlerle değil aynı zamanda mevsimsel tahminlerle de incelenmesi önem taşımaktadır. Çünkü bitkinin dönemsel gelişimi için gerekli olan topraktaki nem miktarı mevsimsel olarak değişmektedir. Her bir bitkinin üreme-büyüme ve gelişme dönemleri farklı zamanlara karşı gelmektedir. Dünya üzerindeki bitkilerin ekim ve sulama zamanlarının değişkenlik göstermesinden dolayı yapılacak yağış 
Mevsimsel Yağışların Jeoistatistiksel Yöntemle Modellenmesi ve ...

haritalarının yıllık ya da aylık ya da mevsimlik olarak elde edilmesi gerekmektedir. Subyanı [16] farklı mevsimlerdeki yağışların mekanizmalarında farklılıkların oluşacağını belirtmiştir. Çalışmasında ise Suudi Arabistan'daki 21 yıllık 63 istasyonun yağış yüksekliklerinin mevsimsel ve yıllık olarak jeoistatistiksel yöntemle haritalandırmasını yapmıştır. Çalışmasının sonucunda yıllık haritanın üstel tip yarıvariogram ile, kış ve ilkbahar aylarının haritalarının üstel tip yarıvariogram ile, yaz ve sonbahar aylarının haritalarının ise küresel tip yarıvariogram ile temsil edilebileceğini belirtmiştir. van de Beek ve ark. [17] Hollanda' daki günlük yağış parametrelerinin mevsimsel variogramlarının analizi için küresel tip yarıvariogram kullanmıştır.

Alansal yağış, baraj ve gölet gibi su depolama amaçlı yapıların kapasitelerinin belirlenmesinde, rezervuarların işletme çalışmalarında, sulama planlamalarında ve taşkın amaçlı rezervuar işletmesinde temel girdi olarak kullanılmaktadır. Havza ve bölgesel bazda günlük ve aylık yağışların jeoistatistiksel yöntemler kullanılarak modellenmesine yönelik çalışmalara sıkça rastlanabilmektedir. Ancak, mevsimsel bazda ve Türkiye ölçeğinde yağışların uzaysal bağımlılık yapılarının saptanmasına yönelik çalışmaların genellikle yetersiz olduğu dikkati çekmektedir. Mevsimsel yağışların modellenmesi ve Türkiye ölçeğinde haritalanması sonucunda elde edilecek bilgiler, yağış bakımından kritik olan yörelerin saptanmasında ve kuraklık çalışmalarında önem arz etmektedir. Bu çalışmada, mevsimsel yağışların uzaysal bağımlılık yapılarının Türkiye ölçeğinde saptanması ve yağış gözlem istasyonu bulunmayan yöreler için mevsimsel yağış tahminlerinin yapılması amaçlanmıştır.

\section{MATERYAL VE YÖNTEM}

\section{1. Çalışma Alanı}

Bu çalışmada, yarı kurak iklime sahip Türkiye sınırları içerisinde yer alan 20 yıl ve daha büyük kayıt uzunluğuna sahip 200 adet yağış gözlem istasyonunun uzun yıllar aylık ortalama yağış değerleri kullanılmıştır. $\mathrm{Bu}$ değerler Meteoroloji İşleri Genel Müdürlüğü'nden (MGM) temin edilmiştir. Çalışmada kullanılan 200 adet meteoroloji gözlem istasyonunun konumları ve Türkiye'deki dağılımları Şekil l'de verilmiştir.

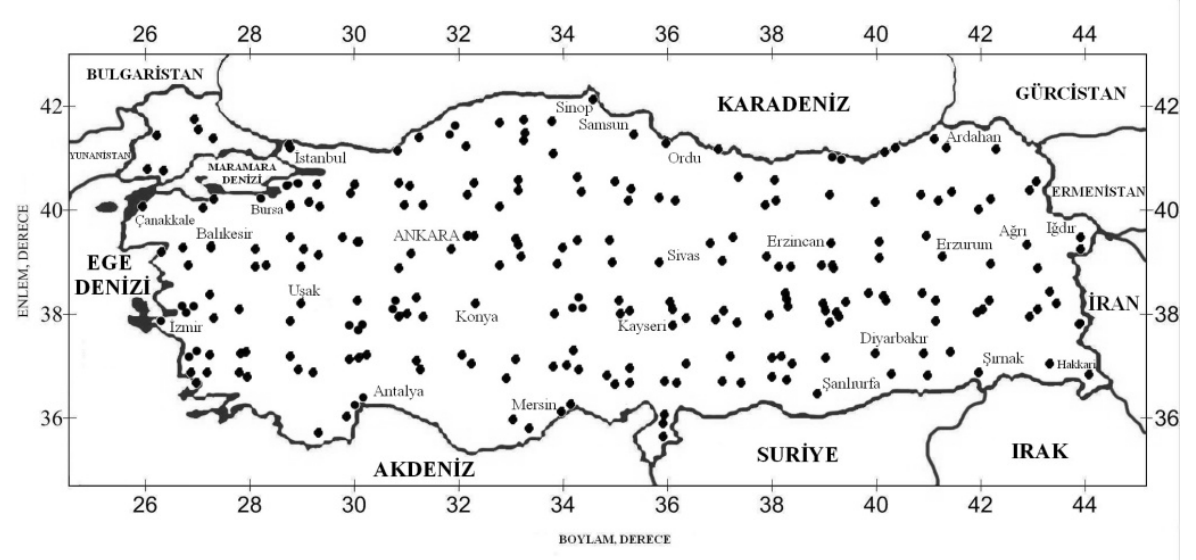

Şekil 1. Meteoroloji gözlem istasyonlarının konumu ve Türkiye'deki dağıllımları 


\subsection{Yöntem}

\subsection{1. İstatistiksel Analiz}

Bilimsel araştırmalarda elde edilen niceliksel veriler genellikle düzensiz durumda bulunur. $\mathrm{Bu}$ verilerin daha iyi anlaşılabilmesi için özet bilgilerin belirlenmesi ve sayısal olarak ifade edilmesi gerekir. Özet bilgilerin belirlenmesi ve yorumlanmasında tanımlayıcı istatistikler yoğun olarak kullanılmaktadır. Tanımlayıcı istatistikler verilerin sınıflandırılarak özet tabloların oluşturulmasını, eğilim ve dağılım ölçülerinin elde edilmesini sağlarlar [5]. Tanımlayıcı istatistikle verilerin işlenmesinde aritmetik ortalama, mod, medyan, standart sapma, çarpıklık katsayısı, basıklık katsayısı gibi ölçülerden yararlanılır.

Niceliksel verilerle ilgili problemlerde değişkenin ortalama değeri en anlamlı parametredir. Çünkü değiş̧kenin merkezi, gözlenecek değerlerin çevresinde dağılacağı değeri gösterir [11]. Niceliksel verilerde ortalama Eşitlik 1 deki gibi hesaplanır.

$$
\bar{y}=\frac{1}{n} \sum_{i=1}^{n} y_{i}
$$

Ortalama değer etrafindaki yayılmayı ölçmek için kullanılan parametre standart sapmadır. Ancak ortalamaları farklı olan değişkenlerin hangisinde yayılmanın daha büyük olduğunu anlamak için standart sapmaların karşlaştırılması gerekmektedir [11]. Eşittlik 2 ile standart sapmanın formulasyonu verilmiştir.

$$
S=\sqrt{\operatorname{var}(x)}=\left[\frac{1}{n-1} \sum_{i=1}^{n}\left(y_{i}-\bar{y}\right)^{2}\right]^{0.5}
$$

Eşitlik 3, değişkenin çarpıklı̆̆ hakkında bilgi vermektedir. Bu sayının sıfıra eşit olması, ortalama çevresinde dağılımın simetrik olduğunu, pozitif olması sağa doğru uzanan bir kuyruğu ve negatif olması ise sola uzanan bir kuyruğu bulunduğunu göstermektedir.

$$
C_{s}=\frac{\left[\frac{1}{n} \sum_{i=1}^{n}\left(y_{i}-\bar{y}\right)^{3}\right]}{S^{3}}
$$

Niceliksel verileri sınıflandırırken kullanılan diğer önemli bir husus da, verilerin basıklığıdır. Basıklık katsayısı, Eşitlik 4 deki hesaplanmaktadır. Değişkenler arasında en büyük $C_{k}$ katsayısına sahip olan değişkenin daha basık olduğu belirtilmektedir.

$$
C_{k}=\frac{\left[\frac{1}{n} \sum_{i=1}^{n}\left(y_{i}-\bar{y}\right)^{4}\right]}{S^{4}}
$$


Mevsimsel Yağışların Jeoistatistiksel Yöntemle Modellenmesi ve ...

Yukarıdaki eşitliklerde kullanılan $n$ değişken sayısını, $y_{i}$ ise niceliksel değişkeni ifadeside edilmektedir.

\subsubsection{Jeoistatistik Analiz}

Jeoistatistiksel yöntemler; doğa olaylarının yersel değişim tavırlarının açıklanmasında, eksik verilerin tamamlanmasında vb amaçların gerçekleştirilmesinde yaygın olarak kulanılan bir yöntemdir [18, 19]. Jeoistatistiksel analizin ilk aşaması yarıvariogram analizlerinin yapılarak uzaysal bağımlılık yapılarının modellenmesidir.

Yarıvariogram; örnek çiftleri arasındaki $h$ uzaklığının bir fonksiyonu olarak incelenen değiş̧kenin uzaysal bağımlılık derecesini ifade eder $[4,5,18,20,21] . x_{i}$ ve $x_{j}$ sirasıyla $i$ ve $j$ gözlem noktalarının koordinatlarını; $z\left(x_{i}\right)$ ve $z\left(x_{j}\right)$ ise $i$ ve $j$ gözlem noktalarında gözlenen değerleri göstermek üzere; $N$ sayıdaki gözlemden oluşan yöresel (yersel) değişken $Z$ ' nin deneysel yarıvariogramı, gözlemler arasındaki Öklid uzaklığı $h$ ' ye bağımlı olarak aşağıdaki gibi hesaplanır $[5,22,23,24,25]$.

$$
\gamma(h)=\frac{1}{2} \operatorname{var}\left[Z\left(x_{i}\right)-Z\left(x_{j}\right)\right] ; i, j=1, N
$$

$\gamma(h)=\sigma^{2}-C(h)$

Populasyon varyası $\sigma^{2}$ ve kovaryansı $C(h)$ ile yarıvariogram değerleri arasında sıkı bir ilişki olup, bu ilişki Eşitlik 6 ile verilmektedir [26]. Gözlem çiftleri arasındaki vektörel uzaklık $h$, koordinatlara bağlı olarak Eşitlik 7 ile hesaplanır [25, 27].

$$
h=\left|u_{i}-u_{j}\right|=\sqrt{\left(x_{i}-x_{j}\right)^{2}-\left(y_{i}-y_{j}\right)^{2}} ; u_{i}=\left(x_{i}, y_{i}\right), u_{j}=\left(x_{j}, y_{j}\right)
$$

Gözlem değerlerinden yararlanılarak hesapla oluşturulan yarıvariograma deneysel yarlvariogram, deneysel yarıvariograma matematiksel bir fonksiyon uydurularak elde edilen yarıvariogram modeline de teorik yarıvariogram denir.

$$
\gamma(h)=\frac{1}{2 N} \sum_{i=1}^{N}\left(x_{i}-x_{j}\right)^{2} ; i, j=1, N
$$

Eşitlik 8 ile deyimlenen deneysel yarıvarigram değerlerinin hesaplanabilmesi için gözlemlerin ikili kombinezyonlarının [28] oluşturulması ve gözlem çiftleri arasındaki $h$ uzaklığının koordinatlar yardımıyla hesaplanması gerekmektedir. $h$ uzaklıklarına karşılık gelen yarıvaryans değerleri karşılıklı olarak grafiklendiğinde, deneysel yarıvariogram elde edilmektedir. Elde edilen deneysel yartvariograma teorik bir model uydurulması ve model parametrelerinin saptanarak uygunluk testinin yapılması ile yartvariogram analizi tamamlanmaktadır [29]. Hidrolojik ve hidrometeorolojik çalışmalarda yaygın olarak kullanım alanı bulan teorik yarıvariogram modellerinin matematiksel eşitlikleri aşağıdaki şekilde verilmiştir [4]. 


$$
\begin{aligned}
& \gamma(h)=C\left[\frac{3}{2} \frac{h}{a}-\frac{1}{2} \frac{h^{3}}{a^{3}}\right]+C_{o} \quad h \leq a \quad \text { Küresel Tip Model } \\
& \gamma(h)=C+C_{o} \quad h>a \\
& \gamma(h)=C\left(1-e^{-3\left(\frac{h}{a}\right)^{2}}\right) \quad \text { Gaussian Model } \\
& \gamma(h)=C_{o}+C_{1}\left(1-e^{-\frac{3 h}{a}}\right) \quad \text { Üstel Model } \\
& \gamma(h)=C(h / a)+C_{o} \quad h \leq a \\
& \gamma(h)=C+C_{o} \quad h>a \\
& \text { Lineer-Sill Model }
\end{aligned}
$$

Burada; $C_{o}$, kontrolsuz etki varyansını; $C$, yapısal varyansı; $h$, gözlem çiftleri arasındaki Öklid uzaklı̆̆ını; a, küresel modelde etki uzaklığını, Gauss ve üstel modelde pratik etki uzaklığını göstermektedir. İncelenen yöresel değişkenin teorik yarıvariogram yapısı matematiksel olarak belirlendikten sonra, çalışma alanı üzerinde gözlemi bulunmayan ya da eksik gözlemli yörelerin noktasal ya da alansal değerleri stradan kriging (Ordinary Kriging) tekniği (Eşitlik 13) ile tahmin edilebilir [5].

Sıradan Kriging, bir tür doğrusal regresyon eşitliği şeklindedir. Ancak, regresyon kat sayıları olarak bilinen ağırlık kat sayıları tahmin edilen noktadan noktaya değişim gösterir.

$$
Z^{*}\left(X_{1}\right)=\sum_{i=1}^{N} \lambda_{j} \cdot Z\left(x_{i}\right)
$$

Burada; $\lambda_{j}$ ağırlık katsayılarını, $Z\left(X_{i}\right)$ gözlenen değerleri, $Z^{*}\left(X_{I}\right), X_{1}$ noktasındaki tahmin edilen değeri gösterir. Ağırlık katsayıları, yansızlık (Eşitlik 14) ve minimum tahmin varyansı (Eşitlik 16) koşullarını sağlayacak şekilde, kriging denklem sisteminin (Eşitlik 14 ve Eşitlik 15) çözümüyle elde edilirler:

$$
\begin{aligned}
& \sum_{j=1}^{N} \lambda_{j}=1 \\
& \sum_{j=1}^{N} \lambda_{j} \cdot \gamma_{i j}+\mu=\gamma_{i o} ; i=1.2, \ldots, N
\end{aligned}
$$

Kriging tahmin hatası, tahminin hata varyansının (Eşitlik 16) karekökü olup, yapılan tahminlerin güvenilirliği hakkında objektif bilgi verirler. 
Mevsimsel Yağışların Jeoistatistiksel Yöntemle Modellenmesi ve ...

$\sigma^{2}=\sum_{i=1}^{N} \lambda_{j} \cdot \gamma_{i o}+\mu$

Burada, $\gamma_{i o}, i$. gözlem ile tahmin yapılan, $o$ noktası arasındaki uzaklığa bağlı olarak elde edilen yarıvaryans değerini; $\mu$ Lagrange çarpanını; $\sigma^{2}$ Kriging tahmin varyansını ve $n$ tahminde kullanılan gözlem sayısını göstermektedir [30].

\subsubsection{Yarivariogram Modeli Uygunluk Testi}

Belirlenen teorik yarıvariogramın çalışma alanını temsil etme niteliği çapraz doğrulama (jack-knifing) olarak da bilinen yöntemle [31,32] yapılabilir. Bu yöntemde indirgenmiş hataların ortalamasının sıfır, varyansının bir olup olmadığı kontrol edilir [27]. İndirgenmiş hataların ortalamas1 ( mean reduced error, MRE) ve varyans1 (reduced variance, RVAR) şöyle hesaplanabilir:

$$
\begin{aligned}
& \text { MRE }=\frac{1}{N} \sum_{i=1}^{N}\left(\frac{Z\left(x_{i}\right)-Z^{*}\left(x_{i}\right)}{\sigma_{k}}\right) \\
& R V A R=\frac{1}{N} \sum_{i=1}^{N}\left(\frac{Z\left(x_{i}\right)-Z^{*}\left(x_{i}\right)}{\sigma_{k}}\right)^{2}
\end{aligned}
$$

Burada, $\mathrm{N}$ toplam örnek sayısını, $Z\left(x_{i}\right)$ gözlenmiş değerleri, $Z^{*}\left(x_{i}\right)$ kriging tahminini, $\sigma_{\mathrm{k}}$ ise tahmin edilen değerin kriging standart sapmasını (kriging hata değerini) göstermektedir.

\section{MODELINN UYGULAMASI}

\subsection{Tanımlayıcı İstatistikler}

Türkiye sinıları içerisinde yer alan 20 yıl ve daha büyük kayıt uzunluğuna sahip 200 adet yağış gözlem istasyonunun (Şekil 1) uzun yıllar aylık ortalama yağış değerleri kullanılmıştır. Herbir mevsime ait ayların uzun yıllar aylık ortalama değerleri toplanarak mevsimsel yağışlar elde edilmiştir. Mevsimsel yağış değerlerinin tanımlayıcı bazı önemli istatistikleri Minitab paket programı [33] ile hesaplanarak Çizelge 1 de verilmiştir. Çizelge incelendiğinde, sonbahar ve yaz aylarında daha büyük olmakla birlikte tüm mevsimlerdeki yă̆ı̧ değerlerinin sağa çarpık olduğu görülmektedir. Yaz mevsimindeki standart sapma, ortalama ile yakın değerdedir. Cs katsayısı göz önüne alındığında, mevsimsel yağışların normal dağılıma uymadığı anlaşııııştır. Ayrıca mevsimsel yağışların basıklık katsayıları (Ck) incelendiğinde hiçbir mevsimde bu katsayı değeri üçe eşit olmaması nedeniyle normal dağılıma uymadığı anlaşılmıştır. 
Çizelge 1. Mevsimsel Yayışların Bazı Tanımlayıcı İstatistikleri

\begin{tabular}{|l|c|c|c|c|}
\hline \multirow{2}{*}{\multicolumn{1}{|c|}{ İstatistik }} & \multicolumn{4}{|c|}{ Mevsimler } \\
\cline { 2 - 5 } & Sonbahar & Kış & İkbahar & Yaz \\
\hline Minimum $\left(\mathrm{X}_{\min }\right)$ & 43.90 & 42.30 & 80.90 & 1.10 \\
\hline Maksimum $\left(\mathrm{X}_{\max }\right)$ & 841.00 & 677.70 & 337.70 & 248.60 \\
\hline Değişim Aralığı & 797.10 & 635.40 & 256.80 & 247.50 \\
\hline Ortalama $(\bar{x})$ & 155.99 & 234.80 & 167.19 & 56.01 \\
\hline Standart Sapma $(\mathrm{S})$ & 101.47 & 128.49 & 46.62 & 48.33 \\
\hline Çarpıklık Katsayısı $(\mathrm{Cs})$ & 3.45 & 1.10 & 1.29 & 1.76 \\
\hline Basıklık Katsayısı $(\mathrm{Ck})$ & 17.71 & 1.17 & 4.43 & 3.42 \\
\hline
\end{tabular}

\subsection{Jeoistatistik Analiz Sonuçları}

Gözlem çiftleri arasında Öklid uzaklıkları h ve bu uzaklıklara ait deneysel yarıvaryans değerleri $[\gamma(h)]$ her bir varyant için yönsüz olarak hesaplanmıştır. Çiftler arasındaki $h$ uzaklığı sınıflandırılarak ortalama uzaklık $(\bar{h})$ ve buna karşılık gelen ortalama deneysel yarıvaryans $(\gamma(\bar{h}))$ değerleri yeniden oluşturulmuş; ortalama $(\bar{h}-\gamma(\bar{h}))$ değerleri karşılıklı olarak grafiklenerek varyansların deneysel yarıvariogramları elde edilmiştir (Şekil 2).

Mevsimlere ait hesaplanan en iyi deneysel yarıvariogram yapıları Cizelge 2'de verilmiștir. Saptanan deneysel yartvariogram şekillerine uygun olarak dört mevsimde de Gaussian Model seçilmiş̧ir. Teorik yarıvariogram modelinin parametreleri saptanmış, model ve parametrelerinin alanı temsil edilebilir nitelikte olup olmadı̆̆ına karar vermek için çapraz doğrulama testi uygulanmıştır [34, 35]. Çapraz Doğrulama testi sonuçları Çizelge 3'de ise ayrıntılı ve Çizelge 4 'te özet olarak verilmiştir. Çapraz doğrulamanın yanı sıra kriging hatalarının ortalamasının sıfır $(0.0)$ ve varyansı en küçük veren model tercih edilmektedir (Başkan, 2004). Hataların ortalamasının sıfır olup olmadığı $\% 5$ önem düzeyine göre normal dağgllm ile kontrol edilmiştir. Teste göre $\% 5$ önem düzeyi ve 200 adet veri için ortalamanın güven aralığ 1 değerleri parantez içinde Çizelge 3'te verilmiştir. Çizelgeye göre hataların ortalamasının sıfır olduğu dolayısıyla kriging hatalarının eğilimi olmadığı yansız tahmin yaptığı görülmektedir. Sonuçta, modellerin alanı temsil edebilir nitelikte olduğuna karar verilmiştir. Sonbahar ile yaz ve kış ile ilkbahar mevsimlerindeki indirgenmiş hataların varyansındaki farklılı̆ıı sebebi olarak kış ve ilkbahar dönemindeki kısa süreli bölgesel yağış̧ardan kaynaklandığ̣ düşünülmektedir. Çizelge 4-7'de verilen gözlenen minimum ve maksimum değerler ile aynı değişkenin tahmin edilen minimum ve maksimum değerleri kıyaslandığında, kriging tahmin tekniğinin yumuşatma, bir diğer ifade ile regresyon etkisi açıkça görülmektedir. Ayrıca çizelgelerden görüleceği üzere tahmin edilen değerlerin standart sapması gözlenen değerlerin standart sapmasından daha küçük olduğu görülmektedir. Bu durum ölçümü olmayan nokta ve/veya alan için tahmin edilen değerlere güvenilebileceğini göstermektedir [35,36]. 
Mevsimsel Yağışların Jeoistatistiksel Yöntemle Modellenmesi ve ...

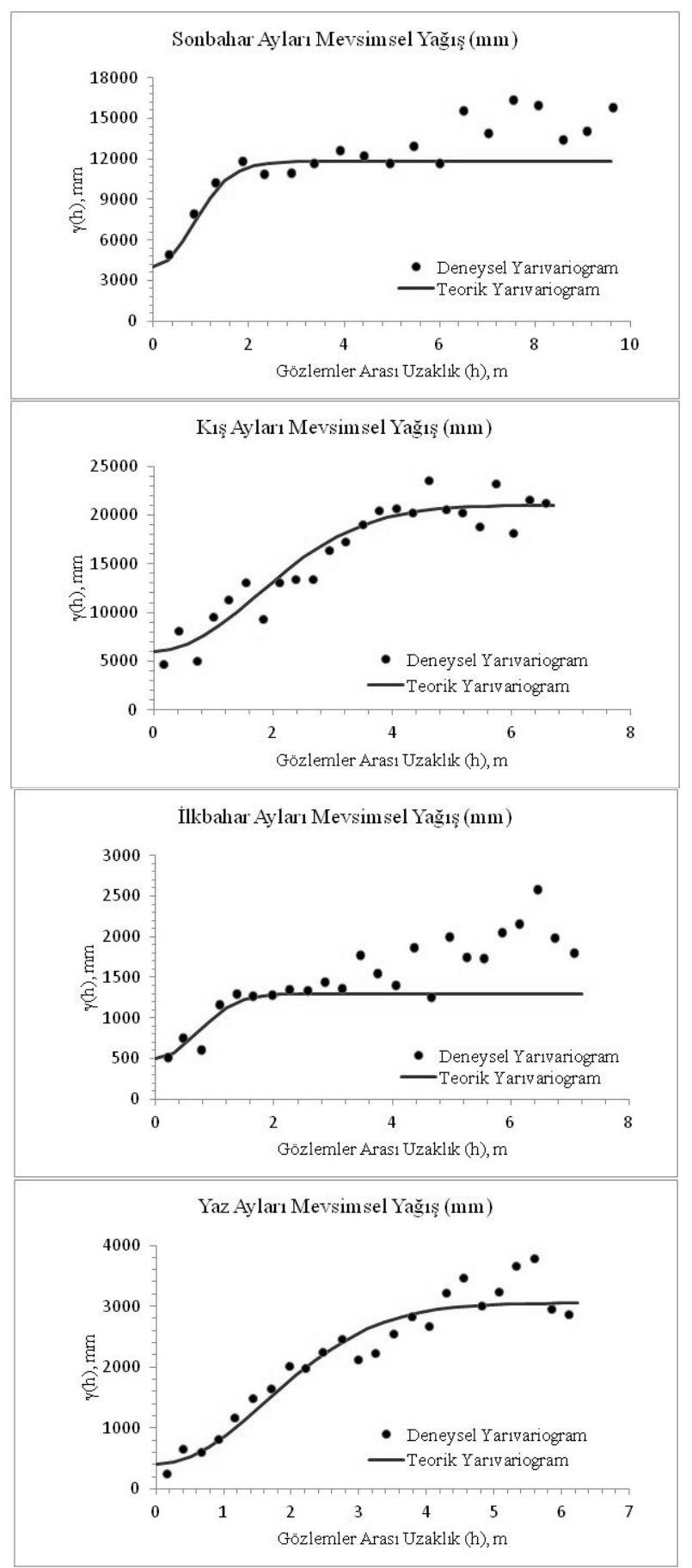

Şekil 2. Her bir Mevsime ait Deneysel ve Teorik Yartvariogramlar 
Mevsimsel yağışlar, diğer doğa olayları gibi rastgele karakter taşımaktadır. Bu yüzden, belirlenen aylık yarıvariogram modelleri kontrolsüz etki varyansı $\left(C_{0}\right)$ içermiştir [37]. $\mathrm{Bu}$ varyansın toplam varyansa $\left(C_{0}+C\right)$ oranı yaz mevsiminde \% 13.1 ile minimum, ilkbahar mevsiminde \% 35.7 ile maksimum düzeyde bulunmuştur (Çizelge 2). Genellikle yağışlı periyotta kontrolsüz etki varyansı artmış, kurak periyotlarda ise azalmalar göstermiştir. Aylık yarıvariogram modelleri için hesaplanan yapısal varyansların toplam varyans içindeki oranı yaz mevsiminde \%86.9 ile maksimum, ilkbahar mevsiminde ise \%64.3 ile minimum bulunmuştur (Çizelge 2).

Çizelge 2. Mevsimsel Yağışlara ait Yarıvariogram Değerleri

\begin{tabular}{|l|c|c|c|c|c|c|}
\hline \multirow{2}{*}{ Mevsimler } & Model & \multicolumn{2}{|c|}{$\begin{array}{c}\text { Kontrolsüz Etki } \\
\text { Varyansı }\end{array}$} & \multicolumn{2}{c|}{$\begin{array}{c}\text { Yapısal } \\
\text { Varyans }\end{array}$} & $\begin{array}{c}\text { Arama Tarama } \\
\text { Yarı̧apı } \\
\text { (km) }\end{array}$ \\
\cline { 3 - 6 } & & $\mathbf{C}_{\mathbf{0}}$ & $\mathbf{\%}$ & $\mathbf{C}$ & $\mathbf{\%}$ & \\
\hline Sonbahar & Gaussian & 4000 & 33.8 & 7800 & 66.2 & 9.5 \\
\hline Kış & Gaussian & 6000 & 28.6 & 15000 & 71.4 & 9.5 \\
\hline İlkbahar & Gaussian & 500 & 35.7 & 900 & 64.3 & 9.5 \\
\hline Yaz & Gaussian & 400 & 13.1 & 2650 & 86.9 & 9.5 \\
\hline
\end{tabular}

Çizelge 3. Dört Mevsim ayları için Çapraz Doğrulama test sonuçları

\begin{tabular}{|c|c|c|c|c|c|c|}
\hline & $\begin{array}{l}\text { Yağ1ş } \\
(\mathrm{mm})\end{array}$ & Gözlenen & $\begin{array}{l}\text { Tahmin } \\
\text { Edilen }\end{array}$ & $\begin{array}{l}\text { Kriging } \\
\text { Standart } \\
\text { Sapma }\end{array}$ & Fark & $\begin{array}{c}\text { İndirgenmiş } \\
\text { Hata }\end{array}$ \\
\hline \multirow{7}{*}{ 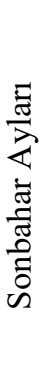 } & Minimum & 43.900 & 63.120 & 67.764 & -492.414 & -6.146 \\
\hline & Q1 & 94.800 & 105.086 & 71.622 & -18.879 & -0.261 \\
\hline & Medyan & 130.300 & 143.630 & 73.957 & 5.241 & 0.071 \\
\hline & Q3 & 176.700 & 179.669 & 76.976 & 21.981 & 0.295 \\
\hline & Maksimum & 841.000 & 634.510 & 101.367 & 331.300 & 4.210 \\
\hline & Ortalama & 154.178 & 154.476 & 75.299 & 0.298 & 0.005 \\
\hline & Std. Sapma & 100.514 & 70.640 & 5.491 & 63.973 & 0.826 \\
\hline \multirow{7}{*}{ 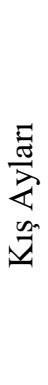 } & Minimum & 42.300 & 71.577 & 82.392 & -314.652 & -3.687 \\
\hline & Q1 & 123.600 & 165.685 & 83.336 & -37.888 & -0.443 \\
\hline & Medyan & 211.200 & 223.141 & 84.051 & 11.426 & 0.138 \\
\hline & Q3 & 309.600 & 283.228 & 85.213 & 55.875 & 0.660 \\
\hline & Maksimum & 677.700 & 500.140 & 100.672 & 275.767 & 3.261 \\
\hline & Ortalama & 233.866 & 234.611 & 84.921 & 0.745 & 0.010 \\
\hline & Std. Sapma & 128.505 & 87.747 & 2.719 & 86.915 & 1.023 \\
\hline
\end{tabular}


Mevsimsel Yağışların Jeoistatistiksel Yöntemle Modellenmesi ve ...

Çizelge 3. Dört Mevsim ayları için Çapraz Doğrulama test sonuçları (devam)

\begin{tabular}{|c|c|c|c|c|c|c|}
\hline & $\begin{array}{l}\text { Yağış } \\
(\mathrm{mm})\end{array}$ & Gözlenen & $\begin{array}{l}\text { Tahmin } \\
\text { Edilen }\end{array}$ & $\begin{array}{c}\text { Kriging } \\
\text { Standart } \\
\text { Sapma }\end{array}$ & Fark & $\begin{array}{c}\text { İndirgenmiş } \\
\text { Hata }\end{array}$ \\
\hline \multirow{7}{*}{ 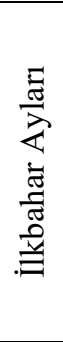 } & Minimum & 80.900 & 100.625 & 27.161 & -117.632 & -4.097 \\
\hline & Q1 & 135.200 & 135.200 & 25.927 & -15.921 & -0.629 \\
\hline & Medyan & 156.600 & 158.218 & 27.042 & 3.612 & 0.140 \\
\hline & Q3 & 185.200 & 184.483 & 28.726 & 18.726 & 0.688 \\
\hline & Maksimum & 337.700 & 291.845 & 36.945 & 93.394 & 3.387 \\
\hline & Ortalama & 167.190 & 167.768 & 27.398 & 0.578 & 0.014 \\
\hline & Std. Sapma & 46.616 & 35.040 & 2.241 & 32.391 & 1.172 \\
\hline \multirow{7}{*}{ 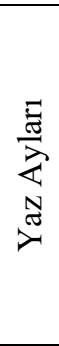 } & Minimum & 1.100 & 4.787 & 21.352 & -90.160 & -3.321 \\
\hline & Q1 & 21.300 & 24.324 & 21.955 & -4.810 & -0.203 \\
\hline & Medyan & 44.600 & 44.363 & 22.333 & 1.364 & 0.059 \\
\hline & Q3 & 67.700 & 74.078 & 23.040 & 8.000 & 0.349 \\
\hline & Maksimum & 244.900 & 202.516 & 30.697 & 70.432 & 3.170 \\
\hline & Ortalama & 54.43 & 54.808 & 22.819 & 0.335 & 0.016 \\
\hline & Std. Sapma & 46.507 & 40.599 & 1.501 & 19.039 & 0.808 \\
\hline
\end{tabular}

Çizelge 4. Model uygunluk testi kriterleri ve sonuçları

\begin{tabular}{|l|c|c|}
\hline \multicolumn{1}{|c|}{ Mevsimler } & MRE & RVAR \\
\hline Sonbahar & 0.005 & 0.826 \\
\hline Kış & 0.010 & 1.023 \\
\hline İlkbahar & 0.014 & 1.172 \\
\hline Yaz & 0.016 & 0.808 \\
\hline
\end{tabular}

Türkiye için gözlenen ve tahmin edilen yağış değerleri Şekil 3' de görülmektedir. Saçılma diyagramlarında görüleceği üzere kriging tahmin yöntemiyle tahmin edilen yağış değerleri, yaz mevsimi dışında diğer aylarda daha dağınık bir yapıya sahiptir. Diğer üç mevsimde de iklimsel ve coğrafi farklılıklar Türkiye geneli için yağışların heterojen bir yapıya sahip olmasına neden olmaktadır. Sonbahar, kış ve ilkbahar mevsimlerine ait saçılma diyagramlarındaki dağınıklığın bu sebeple meydana geldiği düşünülmektedir. Yaz mevsimi dışındaki yağışların görüldüğü diğer üç mevsimde, yağışların bölgelere göre farklılık göstermesi ve kriging tahmin tekniğinin yumuşatma özelliği minimum ve maksimum yağış değerlerinin düşük tahmin edilmesine neden olduğu düşünülmektedir. Bunun diğer bir nedeni olarak maksimum yağışların kıyı kesimlerde meydana gelmesi sonucu sınır etkisinin de tesiri gösterilebilir.

İncelenen değişkenin gözlem yapılmayan noktalardaki alacağ değerlerinin tahmin edilmesinde jeoistatistik teknikler kullanılmaktadır. Bu amaçla, kriging tahmin yöntemi ile 
örneklenmiş yüzeyin istenilen özellikleri tahmin edilmekte ve tahmin sırasında yarıvariogram testi aşamasında belirlenen kriging tahmin parametrelerinden faydalanılmaktadır. Kriging tahmin ve kriging hata haritaları SURFER paket programı [38] yardımıyla, ülkemizdeki mevsimsel yağışlarda kullanılarak, Gaussian tip yarıvariogram modeli yardımı ile kriging tahmin haritaları hazırlanmıştır (Şekil 4). Haritalardan da görüleceği gibi sonbahar ve kış mevsimlerindeki yağış benzer özellik göstermektedir. Fakat sonbahar döneminde Doğu Karadeniz bölgesi, kış döneminde ise Akdeniz bölgesi daha yağışlı geçmektedir. Bu özellikler Türkiye'nin coğrafi konumundan kaynaklanmaktadır. Kriging haritalarından görüleceği üzere denizlerden uzaklaştıkça yağış miktarları azalmaktadır. Özellikle iç Anadolu bölgesinde yağış miktarlarının minimum olduğu gözlenmektedir. İlkbahar haricindeki mevsimler bölgelere göre düzenli bir yağış dağılımı sergilerken ilkbahar mevsiminde belirli alanları etkileyen orografik ve konveksiyon yağışları kriging haritası üzerinde yüksek ve düşük yağış bölgeleri belirlemiştir.
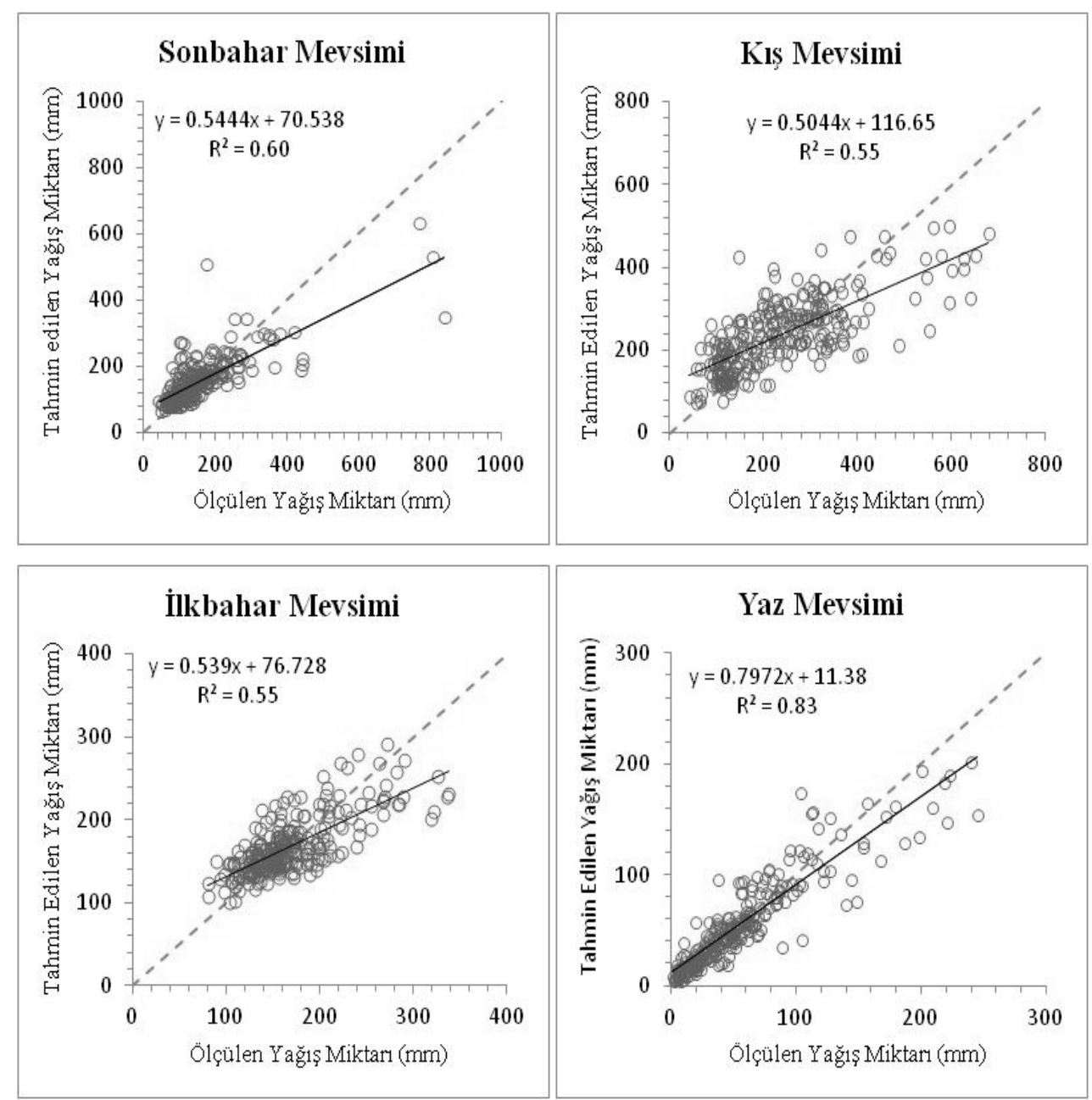

Şekil 3. Yă̆ış Değerlerinin Karşılıklı Etkileşim Diyagramı 
Mevsimsel Yağışların Jeoistatistiksel Yöntemle Modellenmesi ve ...
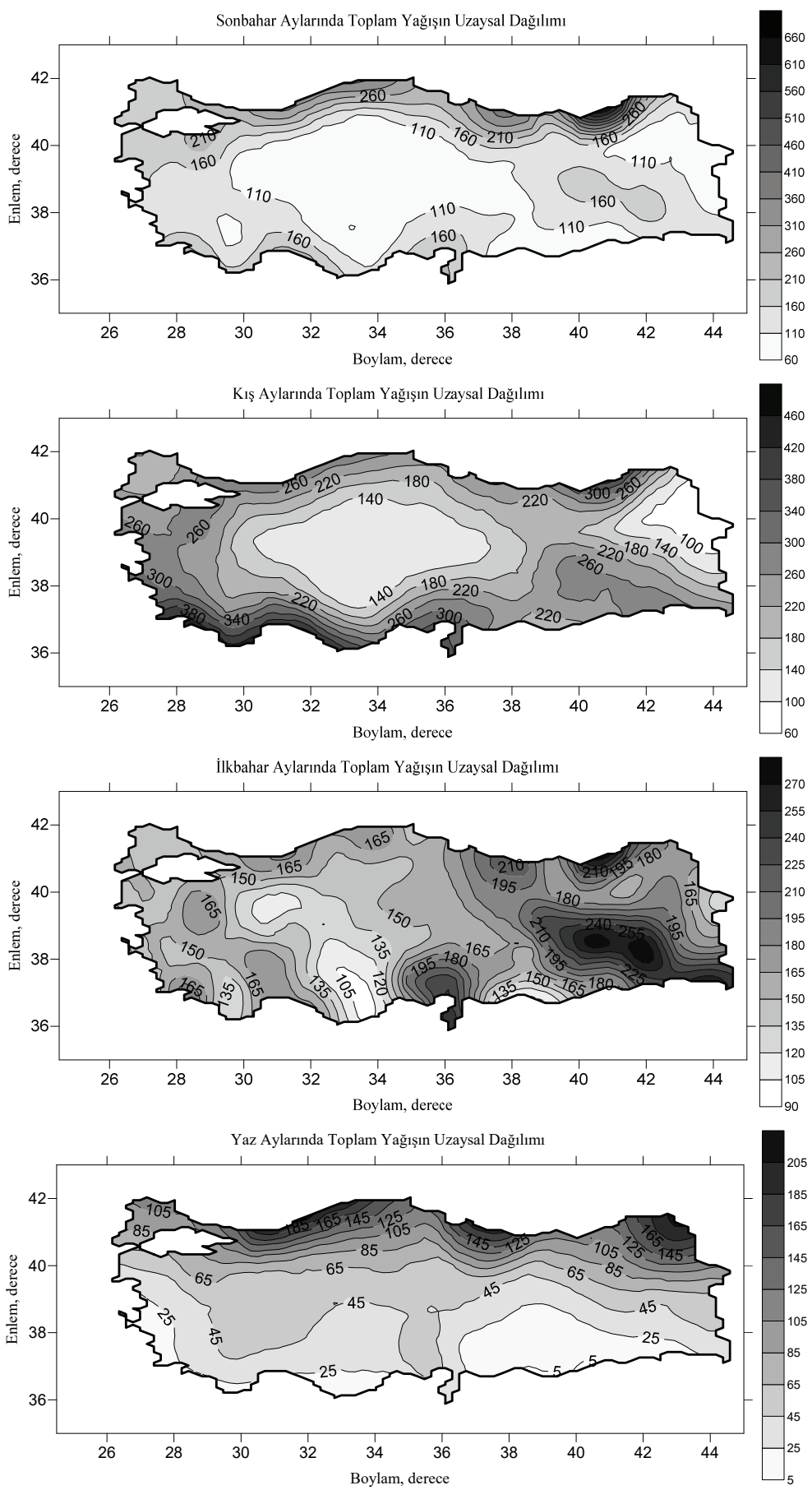

Şekil 4. Mevsimsel Yağışların Kriging Tahmin Haritaları 
Hatice ÇITAKOĞLU, Mahmut ÇETIN, Murat ÇOBANER, Tefarruk HAKTANIR
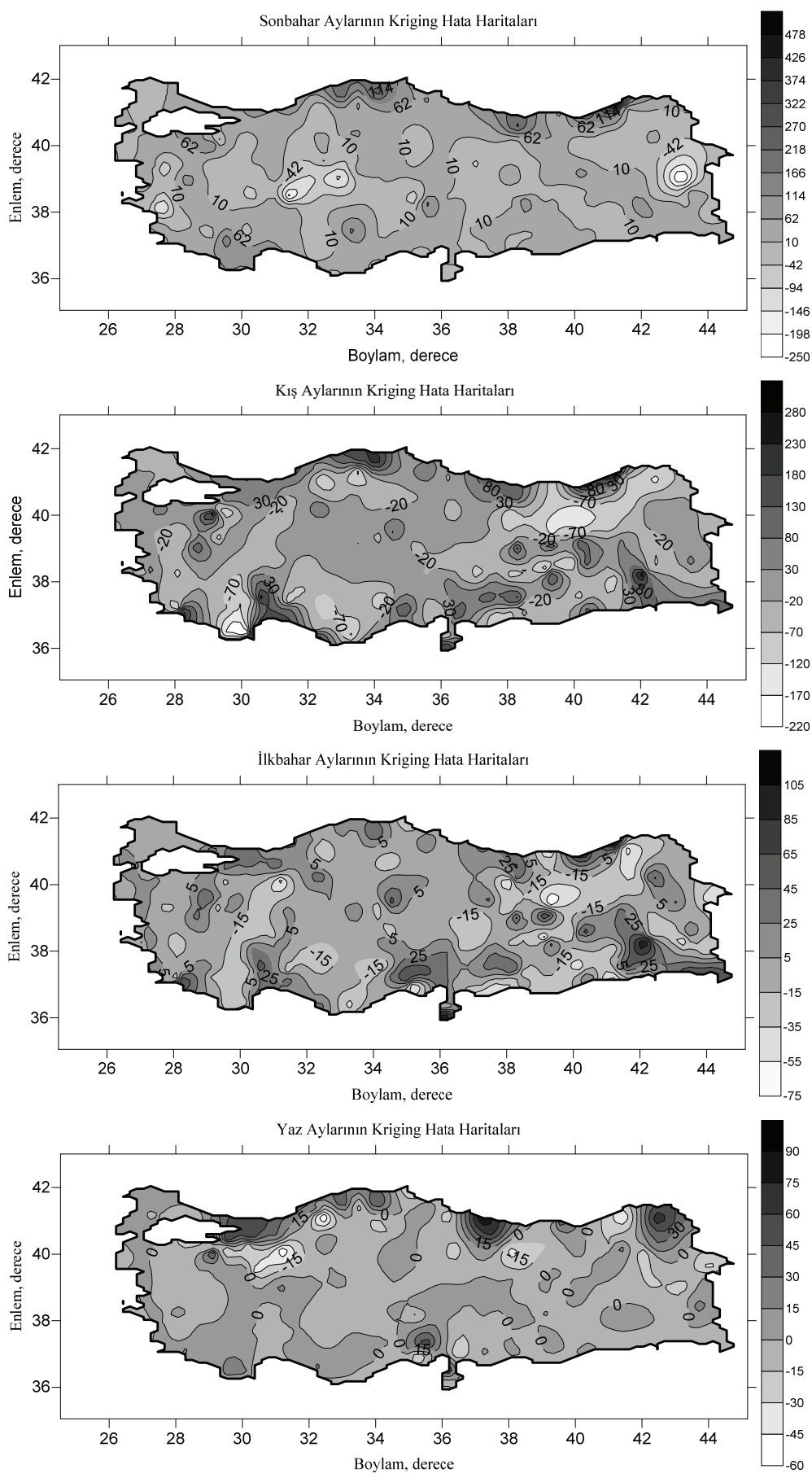

Şekil 5. Mevsimsel Yağış için Kriging Hata Haritaları 
Mevsimsel Yağışların Jeoistatistiksel Yöntemle Modellenmesi ve ...

Şekil 5'deki kriging hata haritaları incelendiğinde iç bölgelerdeki hata değerleri düşükken, deniz kıyısı gibi çalışma alanının sınırındaki yerlerde ise yüksek hata değerleri tespit edilmiştir. Bunun nedenlerinden biri Toros ve Kuzey Anadolu dağlarının denize bakan yamaçlarındaki orografik yağışların fazla olması ve iç kesimlere yağışların geçememesi sonucu iç kesimlerdeki yağışların düşük değerlerde olması kriging tahminlerinde hataların artmasına neden olduğu düşünülmektedir. Kriging hata haritalarındaki yüksek değerlerin olduğu yerler ilave gözlem istasyonlarına gereksinim duyulduğunu, istasyon sayısının bölgeyi temsil etmede yetersiz olduğu anlamına gelmektedir. Bunu yanı sıra iklimsel farklılıklar ve buna bağlı olarak yağış miktarlarındaki farklar oluşturulan kriging tahmin haritasındaki hataların artmasına neden olduğu kanısına varılmıştır.

$\mathrm{Bu}$ çalışmada, yarı kurak iklime sahip Türkiye coğrafyasına düşen yağış miktarlarının kapladığı alanlara göre sınıflandırılması Şekil 6' da verilmiştir. Şekilden görüleceği üzere, ülke yüzölçümünün yaklaşık $\% 45$ 'inde ilkbahar ve sonbahar mevsimlerinde benzer ortalama yağışlar (yaklaşık $190 \mathrm{~mm}$ ) meydana gelmiştir. Yaz mevsimi hariç diğer üç mevsimde Türkiye yüzölçümünün \%50'sinde $180 \mathrm{~mm}$ den fazla, \%100'ünde ise $100 \mathrm{~mm}$ ' den fazla yă̆ı̧̧ gözlenmektedir. Kış mevsiminde Türkiye yüzölçümünün \%72'sine, sonbahar mevsiminde \%94'üne ve diğer mevsimlerde alanın tamamına $300 \mathrm{~mm}$ 'nin altında yağı̧ düşmektedir. Türkiye geneline baktığımızda $200 \mathrm{~mm}$ üzerinde yağış alan bölgeler toplam yüzölçümün sonbahar ve ilkbahar mevsimleri için \%34'ünü, kış mevsimi için ise \%74'ünü oluşturmaktadır. Yaz mevsiminde ise Türkiye yüzölçümünün \%90'ına yaklaşık 120 mm' nin altında yağış düşmektedir.

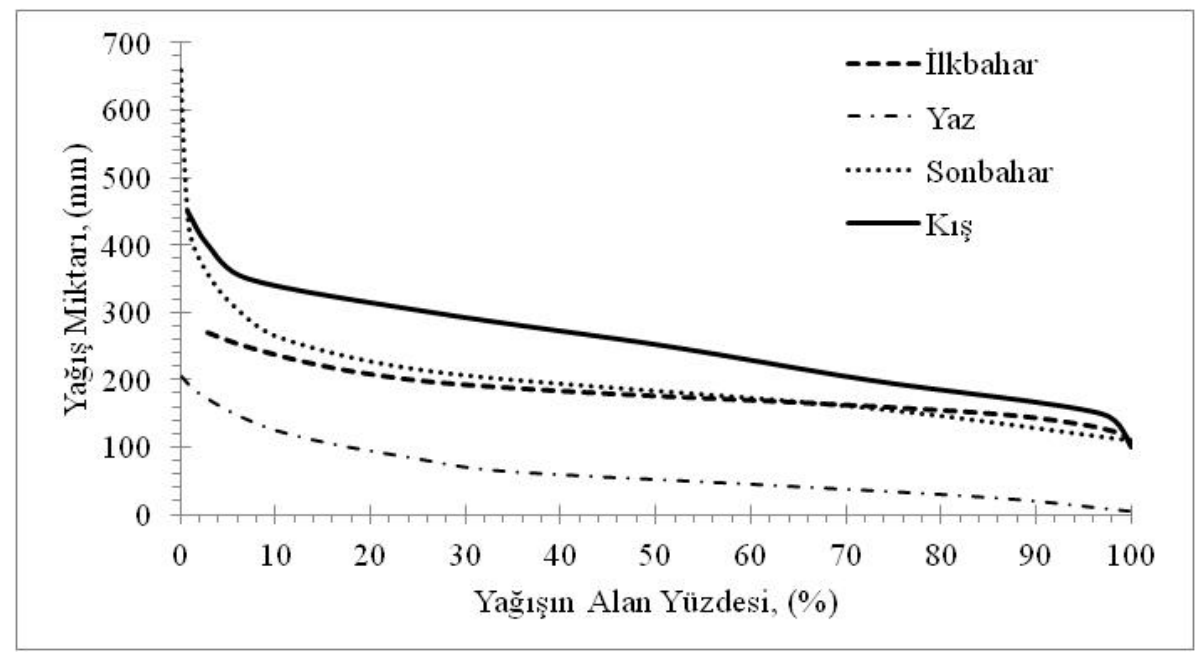

Şekil 6. Mevsimsel Yağışların Kapladığ Alanlar

\section{SONUÇ VE ÖNERILER}

Tabony [39], Avrupa yağış değerlendirme çalışmalarının birçoğunda Türkiye' nin datalarının eksik ve hatalı olmasından dolayı yağış değerlendirme raporlarına dâhil edilmediğini belirtmişlerdir. Meteoroloji Genel Müdürlüğünde (MGM) ise Türkiye’ de yaklaşık $200 \mathrm{~km}$ aralıklarla 285 adet meteorolojik istasyonu mevcuttur. Bu istasyonların 
birçoğunun 20 ylldan az verisi olması sebebiyle istatistiksel olarak değerlendirme yapmak hatalı olacaktır. Bitki sulamalarında ihtiyaç duyulan sulama sistemlerinin hesaplamalarında ise o bölgeye en yakın istasyonun geçmiş yıllara ait verileri çoğu zaman mevcut değildir. $\mathrm{Bu}$ sebeple, mevsimsel olarak elde dilecek haritalar ile bölgenin yaklaşı yağı̧ miktarı hesaplanması gerekmektedir. Bu çalışmada, mevsimsel yağışların değerlendirilmesinde jeoistatistik yöntemle verilerin eğiliminin belirlenmesi ve verilerin birbirlerine göre değişiminin analizi GEOEAS [40] programı yardımıyla gerçekleştirilmiştir. Jeoistatistiksel analiz sonucu, çalışma alanını karakterize etmek için en uygun teorik yarı variogram modeli olarak dört mevsim için de Gaussian model kullanılmıştır. Mevsimsel Kriging yağış haritalardan da görüleceği üzere sonbahar ve kış mevsimlerindeki yağışlar benzer özellik göstermektedir. Fakat sonbahar döneminde Doğu Karadeniz bölgesi, kış döneminde ise Akdeniz bölgesi daha yağışlı geçmektedir. Kriging haritalarından görüleceği üzere denizlerden uzaklaştıkça yağış miktarları azalmaktadır. İlkbahar haricindeki mevsimler bölgelere göre düzenli bir yağış dağılımı sergilerken, ilkbahar mevsiminde belirli alanları etkileyen orografik ve konveksiyon yağışları kriging haritası üzerinde yüksek ve düşük yağı̧̧ bölgeleri oluşturmuştur. Bu sonuçlar bölgesel değişimlerin yağış haritaları üzerinde etkisinin var olduğunu göstermektedir. Çalışma sonunda Türkiye coğrafyasına düşen yağış miktarlarının kapladığı alanlara göre sınıflandırılması yapıldığında kış mevsiminde Türkiye yüzölçümünün \%72'sine, sonbahar mevsiminde \%94'üne ve diğer mevsimlerde ise ülkenin tamamına 300 mm'nin altında yağış düştüğü görülmektedir. Bu sonuçlar Türkiye genelinde yarı kurak iklimin hâkim olduğunu göstermektedir. Türkiye geneline baktığımızda $200 \mathrm{~mm}$ üzerinde yağış alan bölgeler toplam yüzölçümün sonbahar ve ilkbahar mevsimleri için \%34'ünü, kış mevsimi için ise \%74'ünü oluşturmaktadır. Yaz mevsiminde ise Türkiye yüzölçümünün \%90'ına yaklaşık 120 mm' nin altında yağış düşmektedir.

Çalışma alanının mevsimsel yağış haritaları ile hata haritaları incelendiğinde, Toros ve Kuzey Anadolu dağlarının çevresinde oluşan tahmin hataları istasyon sayısının bu bölgede sıklaştırılması gerektiği göstermektedir. Özellikle Doğu ve Güneydoğu Anadolu bölgelerinde kış ve ilkbahar mevsimlerinde meydana gelen tahmin hatalarının ise topografyadaki farklılıklardan ve bölgesel yağışlardan meydana geldiği kansına varılmıştır. $\mathrm{Bu}$ durum yağışlar için kriging tahmin haritası yapılırken Türkiye geneli yerine iklim bölgelerine göre sınır etkilerini de dikkate alacak ayrı yağış haritaları ile daha hassas tahminler yapılabileceğini düşündürmektedir. Çalışma kullanılan yöntem ile yağış gözlem istasyonu olmayan noktalar ve bölgeler için yeterince doğru ve güvenilir tahminler yapmanın mümkün olduğunu göstermiştir. Ayrıca bu yöntem ile ölçülemeyen yağış verisi olan istasyonların eksik verileri bölgedeki diğer istasyonların değerleri de dikkate alınarak tamamlanabilecektir. İklim bölgelerine göre sınır etkilerini dikkate alarak çizilecek kriging yă̆ı̧s tahmin haritalarının daha hassas ve doğru sonuç vereceği düşünülmektedir. Sonraki çalışmalarda bölgesel haritalar ile Türkiye geneli için yapılan haritalar karşılaştırılabilir.

\section{Semboller}

$\begin{array}{ll}\gamma(h) & : \text { Deneysel yarı variogram } \\ \sigma^{2} & : \text { Populasyon varyası } \\ a & : \text { Gözlemlerin birbirinden bağımsız kabul edildiği etki uzaklığı, } \\ C & : C_{o}+C_{l} \text { (Eşik değer veya tepe varyans) }\end{array}$


Mevsimsel Yağışların Jeoistatistiksel Yöntemle Modellenmesi ve ...

$\begin{array}{ll}C(h) & : \text { kovaryansı } \\ C_{l} & : \text { Yapısal ya da stokastik varyans, } \\ C_{k} & : \text { Basıklık katsayısı } \\ C_{o} & : \text { Kontrolsüz etki varyansı, } \\ C_{s} & : \text { Çarpıklık katsayısı } \\ h & : \text { Gözlem çiftleri arasındaki vektörel uzaklık, } \\ \text { MGM } & : \text { Meteoroloji Genel Müdürlü̆̆̈ } \\ \text { MRE } & : \text { İndirgenmiş hataların ortalaması } \\ N & : \text { Gözlem sayısı } \\ n & : \text { Değişken sayısını } \\ \text { RVAR } & : \text { İndirgenmiş hataların varyansı } \\ S & : \text { Standart sapma } \\ x_{i}, x_{j} & : \text { Sirasıyla } i \text { ve } j \text { gözlem noktalarındaki koordinatları } \\ y_{i} & : \text { Niceliksel değişkeni } \\ Z & : \text { Deneysel yarıvariogramı, } \\ Z\left(x_{i}\right) & : \text { Gözlenen değerleri, } \\ z\left(x_{i}\right), z\left(x_{j}\right) & : \text { Sırasıyla } i \text { ve } j \text { gözlem noktalarında gözlenen değerleri } \\ Z^{*}\left(X_{l}\right) & : X_{l} \text { noktasındaki tahmin edilen değeri } \\ Z^{*}\left(x_{i}\right) & : \text { Kriging tahminini, } \\ \lambda_{j} & : \text { Ağırlık katsayılarını, } \\ \sigma_{\mathrm{k}} & : \text { Tahmin edilen değerin kriging standart sapmasını }\end{array}$

\section{Kaynaklar}

[1] Faures, J. M., Goodrich, D. C., Woolhiser, D. A, and Sorooshian, S., Impact of smallscale spatial variability on runoff modeling, Journal of Hydrol., 173, 309-326, 1995.

[2] Chaubeya, I., Haana, C.T., Grunwaldb, S., Salisburyc, J.M., Uncertainty in the model parameters due to spatial variability of rainfall, Journal of Hydrology Vol 220, 48-61, 1999.

[3] Schuurmans, J. M., and Bierkens M. F. P., Effect of spatial distribution of daily rainfall on interior catchment response of a distributed hydrological model, Hydrology and Earth System Sciences, Vol 11, 677-693, 2007.

[4] Çetin, M., Jeoistatistiksel Yöntem ile Nokta ve Alansal Yağışların Saptanması ve Stokastik Olarak Modellenmesi Örnek Havza Uygulamaları, Çukurova Üniversitesi Fen Bilimleri Enstitüsü, Tarımsal Yapılar ve Sulama Anabilim Dalı, Doktora Tezi, Adana, 1996. 
[5] [Tabıos III, G.Q., Salas, J.D., A Comparative Analysis of Techniques for Spatial Interpolation of Precipitation, Water Resources Bulletin, Vol 21, No.3 Pages 365380,1985 .

[6] Önsoy, H., ve Bayram, A., Eksik Yağış Verilerinin Esas Bileşenler Yöntemiyle Tahmini, 5. Ulusal Su Mühendisliği Sempozyumu, 12-16 Eylül 2011 İSTANBUL, 299-305.

[7] Önsoy, H., Kömürcü, M.İ., Bayram, A., Esas Bileşenler Yöntemi ve İklim Bölgelerinin Analizi, 5. Ulusal Su Mühendisliği Sempozyumu, 12-16 Eylül 2011 İSTANBUL, 315-326.

[8] Önsoy, H., ve Bayram, A., MTH Yöntemi Hidrolojik Değişkenlerin Enterpolasyonu, 5. Ulusal Su Mühendisliği Sempozyumu, 12-16 Eylül 2011 ISTANBUL,337-345.

[9] Önsoy, H., ve Bayram, Yağış Verileri ve MTH Yöntemiyle Su Potansiyelinin Hesabı, 5. Ulusal Su Mühendisliği Sempozyumu, 12-16 Eylül 2011 İSTANBUL,361-373.

[10] Karahan, H., Ayvaz, M.T., and Gurarslan, G., "Determination of intensity-durationfrequency relationship by genetic algorithm: Case study GAP", Teknik Dergi, 19(2),4393-4407,2008.

[11] Çetin, M., Özcan, H., Tülücü, K., Aşağı Seyhan ovası (ASO) IV. Merhale proje alanında toprak ve taban suyuna ilişkin bazı fiziksel ve kimyasal özelliklerin yersel değişimlerinin jeoistatistik yöntemle araştırılması, Ç.Ü. Rektörlüğü Münferit Proje Araştırma Projesi Sonuç Raporu (Proje no:ZF/99/14), Adana, 18, 2001.

[12] Buytaert, W., Celleri, R., Willems, P., Bièvre, B.D., Wyseure, G., Spatial and temporal rainfall variability in mountainous areas: A case study from the south Ecuadorian Andes, Journal of Hydrology, Volume 329, Issues 3-4, Pages 413-421, 2006.

[13] Basistha, A., Arya, D. S., and Goel, N. K., Spatial Distribution of Rainfall in Indian Himalayas - A case study of Uttarakhand Region, Water Resources Management, 22, $1325-1346,2008$.

[14] Karahan, H. (2011). "Bölgesel Yağış-Şiddet Süre-Frekans Bağıntılarının Diferansiyel Gelişim Algoritması Kullanılarak Elde Edilmesi", TÜBİTAK (108Y299), Sonuç Raporu, 2011.

[15] Çıtakoğlu, H., L-Momentler Yöntemiyle İç Anadolu'daki Standard Süreli Ekstrem Yağışların Boyut-Süre-Tekerrür Değerlerinin Bölgeselleştirilerek Haritalanması, Erciyes Üniversitesi, Fen Bilimleri Enstitüsü, Doktora Tezi, 2014.

[16] Subyani, A.M., Geostatistical study of annual and seasonal mean rainfall patterns in southwest Saudi Arabia, Hydrological Sciences, 49(5), 803-817,2004.

[17] van de Beek, C. Z., Leijnse, H., Torfs, P. J. J. F., and Uijlenhoet, R., Climatology of daily rainfall semi-variance in The Netherlands, Hydrology and Earth System Sciences, 15(1), 171-183, 2011. 
Mevsimsel Yağışların Jeoistatistiksel Yöntemle Modellenmesi ve ...

[18] Çobaner, M., Çakar, A., Çetin, M., Yurtal, R., Göksu Deltasında Bazı Yeraltı Suyu Kalite Öğelerinin Probabilistik ve Jeoistatistik Yöntemlerle İrdelenmesi, İMO Teknik Dergi, yaz1 341, 5259-5283, 2011.

[19] Burgess, T. M., and Webster, R., Optimal Interpolation and Isarithmic Mapping of Soil Properties I, The Semivariogram and Punctual Kriging. Journal of Soil Science, 31(3), 315-331, 1980.

[20] Olea, R. A., Measuring Spatial Dependence With Semivariograms. Kansas Geological Survey, Series on Spatial Analysis, No. 3,Lawrence, Kansas, 1977.

[21] Kırda, C.; Kanber, R., Toprakların Kimi Fiziksel Özelliklerinde Gözlenen Uzaklık Boyutuna Bağımlı Değişkenlik Tavırları.Yayınlanmamış, Ç.Ü. Ziraat Fakültesi,Kültürteknik Bölümü, Adana, 1983.

[22] Kutílek, M., and Nielsen, D. R., Soil Hydrology. GeoEcology Textbook, Catena Verlag, Germany, 1994.

[23] Olea, R. A., Optimum Mapping Techniques Using Regionalized Variable Theory, Kansas Geological Survey, Series on Spatial Analysis, No. 2, Lawrence, Kansas, 1975.

[24] Vauclin, M., Vieira, S. R., Vachaud, G., and Nielsen, D. R., The Use of Cokriging with Limited Field Soil Observations. Soil Sci. Soc. Am. J., 47, 175-184, 1983.

[25] Kitanidis, P.K., Geostatistics. In the Handbook of Hydrology by Maidment,D.R., (Editor in Chief), McGraw-Hill, Inc.,New York, Chapter 20, 1993.

[26] Isaaks, E. H., and Srivastava, R. M., Applied Geostatistics. Oxford University Press, Inc., USA, 1989.

[27] Journel, A. G. and Huijbregts, C. H. J., Mining Geostatistics. Academic Press, London, 1991.

[28] Willerding, M. F., and Engelsohn, H. S., Mathematics : The Alphabet of Science, John Wiley \& Sons, Inc., Canada, 1977.

[29] Clark, I., Practical Geostatistics. Department of Mineral Resources Engineering, Royal School of Mines,Imperial College of Science and Technology, London, U.K., 1979.

[30] Bayraktar, B., Zemin Ozelliklerinin Coğrafi Bilgi Sistemi Ortamında Mesafenin Tersi ve Kriging Yontemleriyle Kestirimi, Eskisehir Osmangazi Universitesi Fen Bilimleri Enstitusu, Maden Muhendisliği Anabilim Dalı, Yuksek Lisans Tez, Eskişehir, 2007.

[31] Vieira, S.R., Hatfield, J.L., Nielsen, D.R., and Biggar, J.W., Geostatistical Theory and Application to Variability of Some Agronomical Properties, Hilgardia, 51, 3, 1-75, Davis California, 1983.

[32] Deutsch, C.V. and Journel, A.G., Geostatistical Sofware Library and User's Guide, Oxford University Press, Inc., New York, 1992.

[33] Minitab 15, Minitab istatistik paket programı, Minitab, Inc, http://www.minitab.com, 2006. 
[34] Vieira, S.R., Hatfield, J.L., Nielsen, D.R. and Biggar, J.W.1983. Geostatistical theory and application to variability of some agronomical properties. Hilgardia, 51(3); 1-75.

[35] Başkan, O., Gölbaşı yöresi toprakalının mühendislik, fiziksel özellik ilişkilerinde jeoistatistik uygulamas1, Doktora tezi, A.Ü. Fen Bilimleri Enstitüsü, Ankara, 2004.

[36] Trangmar, B.B., Yost, R.J. and Wehara, G. 1985. Application of geostatistics to spatial studies of soil properties. Advances in Agronomy, Vol 38;.65-91.

[37] Çetin, M. ve Tülücü, K., Doğu Akdeniz Bölgesinde Aylık Yağışların Yersel Değişimlerinin Jeoistatistik Yöntemle İncelenmesi, Tr. J. of Engineering and Environmental Science, TÜBİTAK, 279-288, 1998.

[38] SURFER, Surfer for Windows Version 8.02. Golden Software, Inc., http://www.goldensoftware.com, 2002.

[39] Tabony RC. 1981. A principal component and spectral analysis of European rainfall. Journal of Climatology 1: 283-294.

[40] GEOEAS, Geostatistical Environmental Assessment Software: Kriging Software. E. Englund (U.S. EPA) and Allen Sparks (Computer Sciences Corp.), 1989. 
